\title{
1) 花き
}

\section{川田欀一}

全国農業協同組合連合会 農業技術センター

“花き”とは観賞を目的として栽培されている植物の 統称であり，その種類は数千に及ぶものと推定されてい る.これらの花きとその育成に関与した野生種との関係

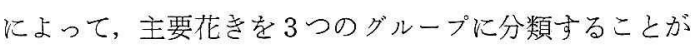
できる(表 1).

A グループ〔野生種とその選抜系が栽培されている花 き）：一・二年草および多年草の多くは，趣味栽培や 庭園用に利用されているのに対し, 球根類, 観葉植物, 観賞樹木は趣味栽培や庭園用とともに切り花, 切り葉, 切り枝, 錸物生産にも用いられている。

B グループ（1 種類の野生種から改良された花さ） Aグループと同様に稔性が高く，採種が容易であるの で, 一・二年草では切り花や花壇苗生産に利用されてい る種類が多い.

Cグループ（種属間交雑に由来する花き）：野生 種 と比べると著しく品種改良が進んでおり，キク，バラ， カーネーション, 雑種ニリ, チューリップ, グラジオラ
スなど, 切り花生産や球根生産に招いて主要な地位を占 める種類が多い.

\section{栽培種と野生種との関係}

\section{1. バラ (英名 Rose)}

現在，切り花および花壇用として栽培されている大 輪，四季咲きの品種はハイブリッド・ティー系に属して いる. 花色は主としてシアニジンによる赤桃色系色素， ペラルゴニジンによる朱赤系色素, カロチノイドによる 黄色系色素加成り立って拈り, 赤䄻色から黄色至る 変異をもつ. シアニジンはRosa gallica とR.chinen-

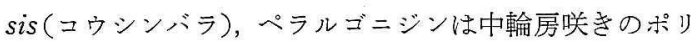
アンサ系に生じた突然変異, カロチノイドは R.foetida に由来している(1). 整った花型と四季咲きは R. chinensis, 強健性はR. moschata と R. multiflora (ノイバラ) に由 来するものと推定される.

R. gallica はバビロニア, ギリシャ時代より栽培され

表 1 口野生種と栽培種との関係による花きの分類

\begin{tabular}{|c|c|c|c|}
\hline 分類 & 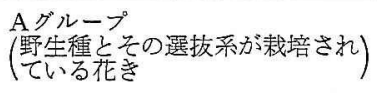 & 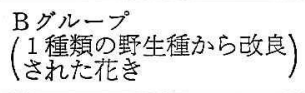 & $\begin{array}{l}\text { Cグループ } \\
\text { （種属間交雑に由来する花き） }\end{array}$ \\
\hline 一・二年草 & $\begin{array}{l}\text { 山野草 } \\
\text { クリサンセマム・ムルチニーレ } \\
\text { クリサンセマム・パルドーサム } \\
\text { ベニジウム }\end{array}$ & $\begin{array}{l}\text { ストック, キンセンカ } \\
\text { コスモス, カスミソウ } \\
\text { キンギョソウ, ケイトウ } \\
\text { スターチス・シヌアータ }\end{array}$ & $\begin{array}{l}\text { ペンジー } \\
\text { デルフィニウム }\end{array}$ \\
\hline 多年草 & $\begin{array}{l}\text { 山野草 } \\
\text { シロタェ゙ク } \\
\text { アカソサス } \\
\text { キンケイギク }\end{array}$ & $\begin{array}{l}\text { キキョウ } \\
\text { ハナショウブ } \\
\text { シュッコンカスミンウ } \\
\text { セキテク }\end{array}$ & $\begin{array}{l}\text { キク,ソリダスター } \\
\text { カーネーショソ, ルルトロメリア } \\
\text { クジャクアスター、西洋オダマキ } \\
\text { ハイブリッド・リモニウム }\end{array}$ \\
\hline 球根 & $\begin{array}{l}\text { ユリ類 } \\
\text { アリウ類 } \\
\text { ヒガソバナ類 }\end{array}$ & $\begin{array}{l}\text { ヒアシンス } \\
\text { グロキシニア } \\
\text { ンクラメン }\end{array}$ & $\begin{array}{l}\text { 雑種ニリ，チニーリップ } \\
\text { 球根アイリス，グラジオラス } \\
\text { ラッパイイセン，ダリア }\end{array}$ \\
\hline ラン類 & 野生種 & 改良種 & 種間交雑種 \\
\hline 観葉植物 & $\begin{array}{l}\text { シダ類 } \\
\text { ヤシ類 } \\
\text { ドラセ類 }\end{array}$ & $\begin{array}{l}\text { アナナス類 } \\
\text { コルディリーネ類 }\end{array}$ & \\
\hline 観頡樹太 & $\begin{array}{l}\text { シャクナゲ類 } \\
\text { タケ, ササ類 } \\
\text { 針垜樹類 } \\
\text { シモクレン } \\
\text { ヤブッドキ }\end{array}$ & $\begin{array}{l}\text { ツバキの園芸品種 } \\
\text { カエデの園芸品種 } \\
\text { アジサイの園芸種 }\end{array}$ & $\begin{array}{l}\text { バラ, ヒラドッッジ } \\
\text { アザレア, カンッバキ } \\
\text { ソメイヨシノザクラ } \\
\text { サラサモクレン } \\
\text { セイヨウシャクナゲ }\end{array}$ \\
\hline
\end{tabular}




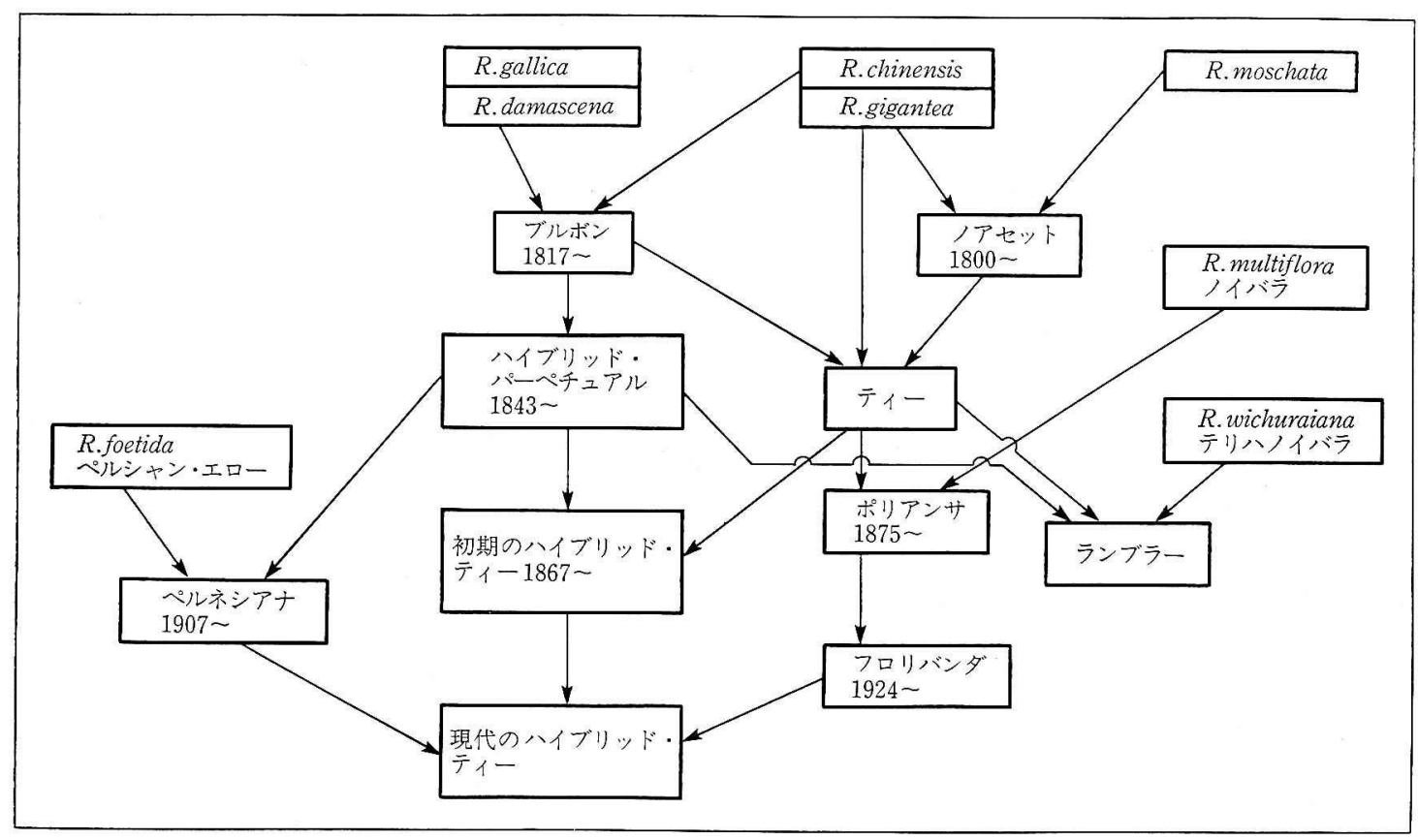

図 1 現代バラの育成経過

ており, 複 2 倍体で八重咲きが多いことからみて, 真の 野生種ではな，園芸品種ではないかとの説もある， $R$. chinensis も中国で 3,000 年前から栽培されており, 四 季咲きで八重咲きであることからみて, 野生種ではなく 園芸品種であるとみられる。

R. moschata は南部ヨーロッパから西部アジアにかけ て分布, R. multiflora は日本, 中国の野生種である. R.foetida は西部アジアの野生種であるが，品種改良に 用いられたのは半八重咲きの園芸品種ペルシャン・エロ ーである.

中輪房咲きのフロリバンダ系は, 強健であるために，花壇用に用いら れている. 四季咲き性はR, chinensis, 房咲き性之強健性は R. multiflora に由来している. 最近, 切り花に用 いられているスプレーバラはフロリ バンダ系あるいはその母体となった ポリアンサ系に属寸る品種に多い.

中〜大輪のつる性のバラには， 、 イブリッド・ティー系, その母体と なったハイブリッド・パーペチュア ル系执よびティー系, 执よびフトリ バンダ系品種の枝変わりによって生
じた品種が多い：これらの品種のつる珄は，R. gigantea とR. moschata 火由来するものと推定される. 小輪房咲 きのランブラー系のつる性は, 日本, 朝鮮, 台湾漳生 する R. wichuraiana（テリハノイバラ）に由来する.

現代バラの育成経過を図 1 に示す.

\section{2. キク (英名 Chrysanthemum)}

栽培ギクは古くは中国に括いて育成されたるのである が, 野生種との関係は明らかではない，北村四郎は，栽 培ギクの染色体数よりみて，チョウセンノギク $(n=9)$
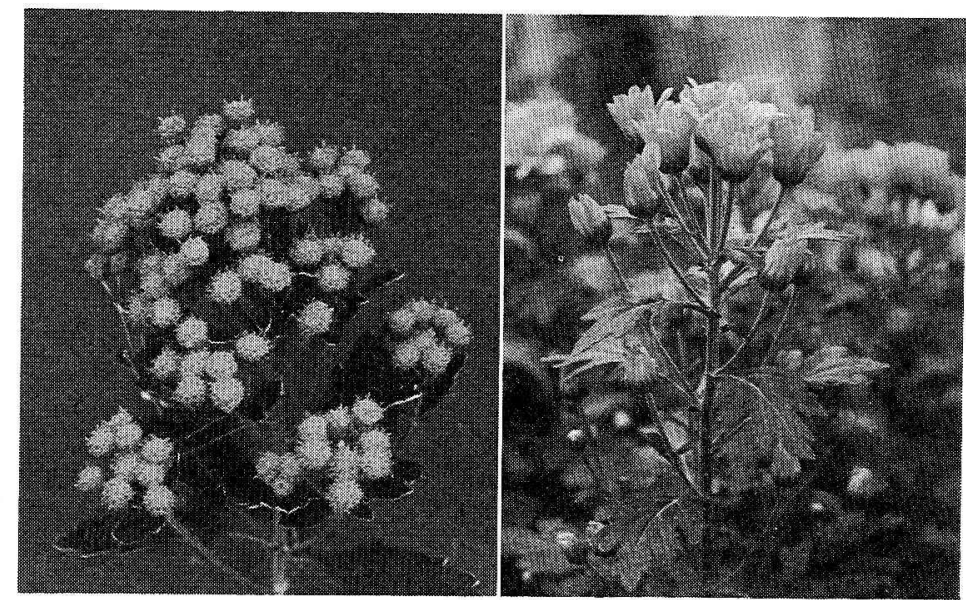

図 2匹イソギク(左)とイソ系スプレーギク(キク農林 5 号, 品種ムーンライト) 
とンマカンギク $(n=18)$ との交雑によって $n=27$ の雑 種ができ，染色体数が倍加したものであると推定してい る. 草姿が両者の中間であること, チョウセンノギクは ロゼットを形成するのに対し，シマカンギクは著しいロ ゼットを形成しないこと，栽培ギクには強いロゼットを 形成する品種とほとんどロゼットを形成しない品種があ ることからみても, 上記の推定は成り立つ.

わが国には栽培ギクと容易に交雑する多くの野生種 (コハマギク，ピレオギク，サッマノギク，シオギク，イ ソギクリュウノウギク，ノジギク）が分布しておら， 文人ギクなど小輪系品種の育成に関与していると推定さ れる. 現在, 沖縄で切り花生産に用いられている品種に はイソギクとスプレーギクの交雑に由来するものがある (図 2).

\section{3. ダイアンサス（英名 Dianthus）}

ダイアンサス属の中でカーネーション (Dianthus caryophyllus）は最も重要な地位を占めている. ギリシ ヤ時代にすでに栽培されており，その野生種との関係は 明らかではない. 16 世紀にはヨーロッパで広く栽培さ れたが，当時の品種は小輪で，春秋の二季咲きであっ た. 19 世紀に至って四季咲き大輪の品種が育成された。 四季咲き性は D. chinensis との交雑に由来するといわれ ているが，正確な記録はない，昭和 40 年代に中輪房咲 きスプレーカーネーションが導入され, 昭和 50 年代後 半にマイク口系, ミディ系, ミニヨン系, ムルチフロラ 系, ディアンティ二系など小輪のさまざまなタイプの園 芸品種が導入された，これらの育成には，ダイアンサス の野生種, 特に D. knapii が利用されている. わが国で はセキチク, カワラナデシコ, ヒゲナデシコ, タツタナ デシコが切り花, 鉢物, 花壇用として栽培されている.

\section{4. ユリ（英名 Lily)}

ユリは北半球に約 130 の野生種が分布している. それ らのうら, 花が美しく園芸的に重要な種類はすべてアジ アに分布している．特にわが国には花の美しい野生種が 集中して分布しており，これらのユリは種間交雑による 園芸品種の育成に利用されている１9 世紀にわが国や 中国の二リが欧米に紹介され，ユリの品種改良が開始さ れた，多くの園芸品種が発表されたが，大部分の品種は ウイルス病に弱く, 普及するには至らなかった。 そこ
でわが国の山野から採集したテッポウユリ，カノコニ リ，ヤマユリ，ササユリなどの球根が欧米に輸出され た. 主要花きで野生種あるい忙と選抜系が切り花や鉢 物などに利用されているのは二リのみといってもよい，

1940 年代に至って, ユリのウイルス病はアブラムシ 類によって伝搬されることが明らかになった。したがっ て, 網室栽培によってアブラムシの発生を防除すれば, ウイルス病の防除ができる. 1970年代には，オランダで は機械油乳剂の葉面散布によるウイルス病防除が行なわ れるよらになった。一方では, 花柱切断受粉と肧培養の 組合せによっで(1), ほとんどすべての組合せの種間雑種 の獲得が可能となり，ユリの品種改良はめざましく進ん だ.

『ユリ年鑑』(英国王立園芸協会，1964 年）では，園芸 分類を栽培品種と野生種との関係によって 8 グループに 分類した. それらのらちで世界的にみて重要なものは以 下の 3 グループであり，いずれもわが国の野生種を中心 として育成されたものである。

\section{1) アジアテック・ハイブリッド}

わが国のエゾスカシニリ，イワトユリ，ヒメユリ，ス ゲニリ，オニユリ，コオニニリ，中国北部および朝鮮半 島のコマユリ，イトハュリ，マツバニリ，中国北部の

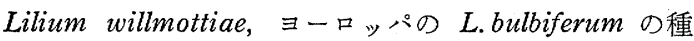
間雑種に由来する．花色はマツバュリを除けばすべてカ ロチノイド系色素を主体としており，黄色からオンンジ 赤に至る変異を示す.

わが国で古くから栽培されてきたスカシュリは，江戸 時代にエゾスカシュリとイワユリの交雑によって育成さ れたものと推定されている. 草丈は低く, 切り花は生け 花の根締めとして利用されていた，戦後アメリカからオ ニュリの血を引く強健で草丈の高いエンチャントメント が導入され, スカシュリとの交雑が重ねられて, 今日の 草丈の高いスカシニリ系品種が䏍成された.

欧米ではスカシュリ，オニュリ，コオニニリなどの交 雑によって, 多くの品種が育成された. 特に, マッバニ リの血を引くクリーム色の品種スターリング・スター, 白色品種モンブランはカロチノイド系色素を含まず, 後 代に淡黄色，桃色品種があらわれ，花色が豊富になった。

2) オリエンタル・ハイブリッド

カノコユリ, ヤマユリ, ササユリ，オトメュリ，ウケ ユリ, タモトユリの雑種である.これらのユリはスカシ 


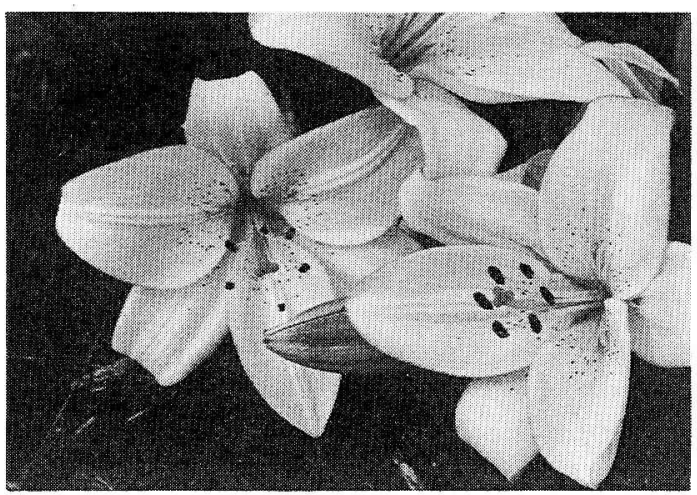

図 3 ロテッポウユリとモンブランの雑種後代（オランダ 園芸植物育種研究所)

エリに比ベてウイルス病や球根腐敗病に弱く, 栽培が困 難であったため,アジアテック・ハイブリッドに比べて 品種改良が遅れた。

ヤマユリ，特にその一系統であるサクュリは，コリの 中では花が最も大きく，花型が整っており，香りも強 い。乙か乙，白色地に黄色条斑，まれに濃桃色の条斑を もつものも市り, 花色の変異は小さい.ナマユリとカ， コニリの雑種はL.xparkmanii (1986) と呼ばれ, 最も美 しい桃色のニリであったが，ウイルス病に弱く普及しな かった.この組合せで発芽能力のある種子が得られるこ とはまれであるが，胚培養によって容易に雑種が得られ ることが明らかにされた（中島 1940）、筆者ら (2)は胚培 養によって得たこの組合せの雑種にナマニりを戻し交雑 すると, カノコニリのもつ純白色の花色とヤマユリの整 った花型をるつ固体が分離することを明らかにした。現 在, 最も人気のある品種カサブランカは, 同様の組合せ により育成されたものと推定される，ル・レーブは淡桃 色，受け咲きで最も優美なユリである．整った花型はヤ マニリ，美しい桃色はササュリまたはオトメユリ，受け 咲きはタモトニリに由来するものと推定される，タモト ニリの草文が低い性質も受け継いでいる.

\section{3）ロンギフロラム・ハイブリッド}

テッポウニリ, タカサゴュリとその近縁種間の雑種群 である、シンテッポウニリは，テッポウユリとタカサゴ こリの雑種に由来し，1951 年西村進によって育成され た. 花型，草姿はテッポウュリに似ており，実生当代に 開花する性質はタカサゴュりの形質を受污継いでいる。

このグループは，他のグループとは交雑しないものと 考えられてきたが，今日では胚培責の利用により，ヤマ
ユリ，オトメニリ，ササニリやアジアテック・ハイブリ ッド系品種との雑種も得られている(図 3).テッポウ土 リは比較的球根生産が容易であり，促成栽培にも適する ので，テッポウニリを中心とした種間雑種ニリの発展が 期待されている.

\section{4. 近年登場した花き}

昭和 50 年代の洋花ブームとともに, いくつかの新し い花きが登場した。

野生種が栽培化された花としてはシロクジャクがあ る. 北米原産で, 昭和 50 年代に至り植松盾次郎によっ てその開花調節技術が開発され，周年的な切り花生産が 行なわれるよらになった、トルコギキョウも北米原産の 野草である。もともと花は紫または白色であったが，昭 和 50 年代にわが国で盛えに品種改良が行なわれ，桃， 淡黄, 覆輸, 八重咲きなど多様な花色と花型をもつ園芸 品種が育成された，その開花調節技術も開発され，今日 ではほ涪周年にわたって市場に出荷されるようになり， 主要花きとしての地位を確保した。

種間交雑によって育成された花きとしては,シロクジ ヤクと宿根アスターの交雑によるシンクジャク(クジャ クアスター), Limonium latifolium と L.bellidifolium の交雑によるハイブリッド・リモニウム，19 世紀に育 成されたが 1980 年代に切り花生産に利用され始めたり リダコ(アキノキリンソウ属)とアスターの交雑によ るソリダスターがある. デルフィニウムはヨーロッパで 19 世紀に種間交雑育種が始められ, 長大な花穂と青柴 色を中心とした多彩で美しい花色の品種が育成された。 切り花水揚げ剤 STS の利用によって花持ちが向上し，

表 2 曰花きの種間交雑育種における野生種の役割

\begin{tabular}{|c|c|c|}
\hline 導入された形質 & 花き名 & 用いられた野生種 \\
\hline 黄色の花色 & $\begin{array}{l}\text { バラ } \\
\text { カーネーション } \\
\text { ハナショウブ }\end{array}$ & $\begin{array}{l}\text { Rosa foetida } \\
\text { Dianthus knappii } \\
\text { Iris preudacorus (キシ } \\
\text { ヨウブ) }\end{array}$ \\
\hline 四季咲产性 & $\begin{array}{l}\text { バラ } \\
\text { カーネーション }\end{array}$ & $\begin{array}{l}\text { Rosa chinensis } \\
\text { Dianthus chinensis }\end{array}$ \\
\hline $\begin{array}{l}3 \text { 倍体による } \\
\text { 不稳性 }\end{array}$ & $\begin{array}{l}\text { チェーリップ(ダ } \\
\text { 一ウィン・ハイブ } \\
\text { リッド系) }\end{array}$ & $\begin{array}{l}\text { Tulipa fosteriana 品種 } \\
\text { レッド・エソペラー }\end{array}$ \\
\hline 房咲き性 & $\begin{array}{l}\text { バラ(ポリアンサ } \\
\text { 系,フロリバンダ } \\
\text { 系) }\end{array}$ & $\begin{array}{l}\text { Rosa multiflora (ノィ } \\
\text { バラ) }\end{array}$ \\
\hline $\begin{array}{l}\text { 耐暑性および } \\
\text { つる性 }\end{array}$ & $\begin{array}{l}\text { バラ(ランブラー } \\
\text { 系) }\end{array}$ & $\begin{array}{l}\text { Rosa wichuraiana (テ } \\
\text { リハイイベラ) }\end{array}$ \\
\hline
\end{tabular}


わが国では 1980 年代に至って切り花生産が普及した.

\section{花きの種属間交雑育種における野生種の役割}

これまで栽培種と野生種との交雑によって新形質の導 大が行なわれてきた。 その例を表 2 に示す. 種間雑種に は 2 基 3 倍体による不稔が偶発することが多い。これら は一般に栄養繁殖力が強い.
文献

1）淺野義人, 明道 博: 園学雑, 46(1)，59 (1977).

2) 阿部定夫, 川田穣一：新花卉，51，21（1960）.

3）有隅健一：九大農学芸雑誌，20，131，1963.

4）川田穣一：“キク’, “植物遺伝資源集成 第 3 巻”, 講談社, 1989 , p. 1046.

5）清水基夫：“日本のキク”，誠文堂新光社，1987.

6) 山口 隆: ‘カーネーション’, “植物遺伝資源集成 第 3 巻”, 講談社, 1989 , p. 1025.

\section{2) 果樹}

\section{畺田哲朗}

農林水産省果樹試験場

果樹には, バラ科, ミカン科, ブドウ科, ツッジ科な ぞ 30 を超觉る科が含まれる. 我が国で栽培されている 主要な果樹を見ても，バラ科のリンゴ，ニホンナシ，セ イヨウナシ，モモ，スモモ，アンズ，ウメ，オウトウ， ビワなどの他, ミカン科のカンキッ, キンカン, ブドウ 科のブドウ，カキノキ科のカキなどと多岐にわたってお り，本稿では多くの樹種が含まれるバラ科果樹を中心に 述ベる.

\section{リンゴ}

リンゴの栽培品種の注とんどは Malus pumila var. domestica で, 原産地はコーカサスを中心とする地域(1) とされている. M. astracanica や M. sylvestris も一部利 用されて招り，我が国や中国ではこれら栽培種(苹果) の導入以前に, M. asiatica（林檎）も利用されていた.

栽培の歴史は古く, ヨーロッパでは紀元前 2000 年以 前から栽培されていたと推定されているが，この頃は品 種が分化して拉らず, 西暦 77 年に出版された書物にな って 29 品種が記載されている(2). 我が国へは明治初期 に, 75 品種の栽培リンゴが導入されており, 現在でも多 少栽培されている「紅玉」もこの時に導入された品種で ある. その後も海外で育成された品種が導入され, 導入 品種の直接利用が行なわれてきた. これらの導入品種は 直接栽培される他, 品種改良の素材としても利用され, 「ふじ」,「つがる」など多くの品種が育成され, 現在, 国内で育成された品種は生産量の $70 \%$ 以上を占めるに 至っており，海外での栽培面積も増加している.
野生種は, M.halliana, M. baccata, M.prattii, M. sielbodii などが中国を中心とする東アジア，M. sylvestris，M.spectabilis などがヨーロッパ和よび西アジア， M.ioensis, M. soulardii などが北米に分布するとされ， 北半球に約 30 種が分布すると報告されている.

野生種の利用については, 果樹では一般に台木に穂品 種を接木した樹が栽培されるため，台木と穂品種とに分 けて述べる。

台木としては, 土壤病害虫抵抗性, 耐寒性, 插木発根 性などが重要な形質である，台木には，古くは栽培品種 や野生種の実生が利用されており，我が国ではミッバカ イドウ（M. sieboldii）の実生や挿木発根性のあるマルバ カイドウ (M.prunifolia var. ringo) が利用されてき た.しかし，イギリスの試験場で，ヨーロッパで古くよ り利用されていた栽培りンゴの近縁種の M. pumila var. paradisiaca に属する系統を集め，矮化効果のある， 系統を選抜し，M，MM 系台木が育成された。最近，こ れら矮性台木の優良性が認められ, 我が国をはじめ多く の国で利用されている. しかし，M，MM 系台木にも㨀 木が困難である点や耐寒性が劣るなどの欠点があり，我： が国では，M 9 や M 26 と挿木発根性のあるマルバカイ ドウとの交雑により捙木発根性のある矮性台木系統が選: 抜され, 現在, 地域適応性試験が実施されている。ま た，冬の寒さの厳しいアメリカやロシアでは，耐寒性の ある M. baccata が用いられてきたが，耐寒性の乏しい $\mathrm{M}, \mathrm{M} M$ 系台木は利用できず, $\mathrm{M}, \mathrm{MM}$ 系統と $M$. baccata その交雑により耐寒性のある矮性台木が育成さ 